\title{
Relationship Between Coping Strategy and the High-Risk Relapse Situation Among Drug Offenders
}

Fauziah Ibrahim, Ezarina Zakaria, Mohammad Rahim Kamaluddin, Nurul Atikah Yunos, Nazirah Hassan \& Wan Shahrazad Wan Sulaiman

To Link this Article: http://dx.doi.org/10.6007/IJARBSS/v11-i3/8950 DOI:10.6007/IJARBSS/v11-i3/8950

Received: 01 February 2021, Revised: 25 February 2021, Accepted: 05 March 2021

Published Online: 17 March 2021

In-Text Citation: (Ibrahim et al., 2021)

To Cite this Article: Ibrahim, F., Zakaria, E., Kamaluddin, M. R., Yunos, N. A., Hassan, N., \& Sulaiman, W. S. W. (2021). Relationship Between Coping Strategy and the High-Risk Relapse Situation Among Drug Offenders. International Journal of Academic Research in Business and Social Sciences, 11(3), 422-430.

Copyright: (c) 2021 The Author(s)

Published by Human Resource Management Academic Research Society (www.hrmars.com) This article is published under the Creative Commons Attribution (CC BY 4.0) license. Anyone may reproduce, distribute, translate and create derivative works of this article (for both commercial and non-commercial purposes), subject to full attribution to the original publication and authors. The full terms of this license may be seen at: http://creativecommons.org/licences/by/4.0/legalcode

Vol. 11, No. 3, 2021, Pg. 422 - 430

Full Terms \& Conditions of access and use can be found at http://hrmars.com/index.php/pages/detail/publication-ethics 


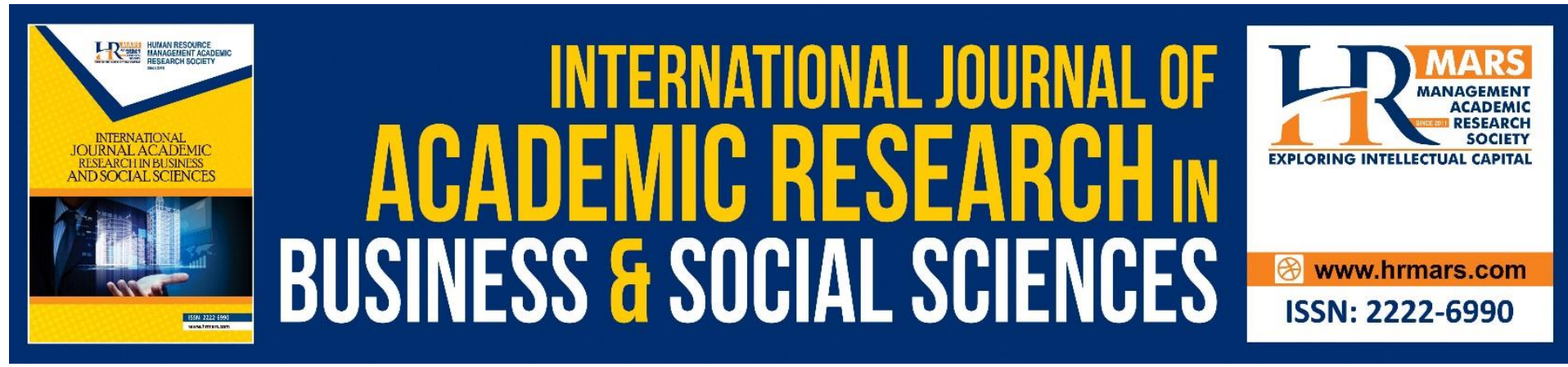

\title{
Relationship Between Coping Strategy and the High-Risk Relapse Situation Among Drug Offenders
}

\author{
Fauziah Ibrahim, Ezarina Zakaria, Mohammad Rahim \\ Kamaluddin, Nurul Atikah Yunos, Nazirah Hassan \& Wan \\ Shahrazad Wan Sulaiman
}

Centre for Research in Psychology and Human Well-Being, Faculty of Social Sciences and Humanities, Universiti Kebangsaan Malaysia, 43600 Bangi, Selangor

Email: ifauziah@ukm.edu.my

\begin{abstract}
Coping strategy is an important aspect that needs to be studied and predict the long-term recovery success process among individuals involved with drugs. Effective coping strategies help prevent individuals from repeating drug addiction behaviours. Therefore, this research was conducted to (1) identify the coping strategies used by drug offenders and (2) analyse the relationship between coping strategies and high-risk relapse situations among drug offenders. The research was conducted in a cross-sectional survey using quantitative methods. A total of 301 prisoners involved in drug cases and currently undergoing detention and rehabilitation at Malaysian Prisons Department were selected as respondents. The data collected were analysed using descriptive tests and Pearson correlation. The research results attained that majority of prisoners who are undergoing rehabilitation and detention in Malaysian Prisons use problem-focused coping strategies to free themselves from drugs. In addition, Pearson correlation analysis indicated that coping strategies had a significant relationship with highrisk relapse situations among prisoners. The results have implications for the stakeholders in the provision of effective educational programs, drug rehabilitation and skills training to prisoners.
\end{abstract}

Keywords: Prisoners, Malay, Drugs, Crime, Drug Offenders

Introduction

Coping strategies play an important role in the treatment and rehabilitation process to prevent an individual from getting involved in recurring drug addiction activities. Coping strategy refers to the various ways of thinking and behavior used by an individual to deal with stressful situations, whether internal or external stress (Fortier and Dilillo, 2010). It also depends on the ability of former addicts to deal with relapse and maintain a drug-free lifestyle (Hasking, et al., 2011; Sussman, 2012; Razali, 2018). Coping strategies consist of various cognitive and behavioral strategies used by an individual to control stress and problems encountered in life, including health and drug addiction (Hasking and Oei, 2004; Sanchez et 
al. 2010). Individuals with adaptive coping are inclined to deal with daily stress better (Arena et al., 2017; Nur Saadah \& Hilwa, 2015). Previous research emphasise that coping strategies play an essential role in addressing recurring drug addiction (Kiluk, et al., 2011; Valentino, et al., 2010; Sinha, 2008; Hadijah, et al., 2018). The researches show that addicts who use effective coping strategies are more likely to maintain recovery than addicts who do not use coping strategies when faced with problems (Annis, Sklar and Moser, 1998; Fauziah, et al., 2012). The study results showed that respondents who used two or more coping strategies were more likely to maintain recovery than those who used only one type of coping strategy.

Researches show that most drug addicts will usually return to drugs to deal with the inevitable stresses or problems they face in life (Dennis, et al., 2005; Dennis, et al., 2007; Mustapha, et al., 2020). These findings connote that taking drugs is one of the strategies used to relieve stress among addicts. Psychologically, drug addicts will rely on drugs to deal with a problem if they do not have a coping strategy that can be applied in their lives. However, if they have a coping strategy, they can choose to maintain recovery or vice versa. Thus, the inability to devise effective coping strategies is a major obstacle in maintaining recovery and, in turn, affects their goal of releasing themselves from drugs. Researches have revealed that drug addicts in recovery use cognitive coping strategies to avoid repeated addiction (Gossop et al., 2002). There are several types of coping strategies used by addicts to avoid drugs. Among the types are avoiding approaching drug trafficking areas, choosing to associate with non-addicts and immediately seeking counselling services to maintain recovery (Ison et al., 2006; Brechting \& Giancola, 2007).

Other researchers explain that problem-focused coping strategies allow a former addict to identify the problems encountered and subsequently make plans to protect themselves from engaging in re-addiction (Eitlea and Eitlea, 2015). There are four defence mechanisms that can help treat drug addiction problems using logical analysis, seeking guidance and support, and expressing feelings (Dennis et al., 2007). Such mechanisms depend on the lifestyle and form of recovery used to recuperate and be drug-free. In short, the coping strategy is a protection strategy that can help prevent recurrent addiction from occurring among drug addicts. The religious aspect is also one of the best coping strategies that can be used to prevent addicts from re-addiction and health care (Norhayati, et al., 2015). A strong religious background and determination to deepen religious knowledge can give peace and free oneself from drugs (Murnizam, et al., 2010). This finding is supported by previous researches that discovered that religiously focused coping strategies became the primary alternative for former addicts to quit and avoid re-addiction (Mahmood, Shuaib and Lasimon, 1999). Those who have the intention to retake the drug are seen to stay away from peers who are still addicted. This action aims to prevent themselves from being influenced by peers, causing them to be involved with drug addiction activities again.

Based on previous researches, it can be concluded that coping strategy skills play an important role in helping a person to fight warning signs against addiction. In fact, coping strategies are also significant predictors of treatment outcomes received in the drug recovery process (Litt, et al., 2003). Effective coping strategies can help a person overcome the problem of a psychological dependence on drugs. Since the coping strategy aspect is vital to help avoid drugs, this research was conducted to identify the types of coping strategies used by drug offenders and analyse their relationship with high-risk relapse situations. The research results 
are expected to provide useful information sources for the stakeholders, especially the prison management, to provide effective educational, drug rehabilitation and effective skills training programs to prisoners involved in drug cases.

\section{Research Methodology}

Research Design: This research uses quantitative cross-sectional survey methods. It was conducted using a survey questionnaire. Quantitative research uses numerical data throughout the process, beginning from data collection, data interpretation and presentation of findings (Arikunto, 2006).

Research Population, Sample and Location: In this research, the population refers to drug offenders serving sentences in Malaysian Prisons. A total of 301 drug offenders placed in five prisons zones were selected as samples. Among the prisons involved in the research are from the southern zone (Melaka Prisons), the central zone (Selangor Prisons), the northern zone (Perak Prisons), the eastern zone (Pahang Prisons) and the Sabah / Sarawak zone (Prisons Sabah). All those involved in this research were: (1) Malay drug offenders serving time in prison for at least six months.

Research Instruments: The research instruments are as follows:

1. Coping Strategy: This test tool was developed by Fauziah, et al., (2016) and comprised of 16 questions items to measure coping strategies for drug-free among prisoners. This aspect emphasizes three types of coping strategies, namely; (i) problem-focused strategies (5 items), (ii) emotional-focused strategies (6 items) and (iii) avoidance-focused strategies (5 items). The scale of reliability value is high at 0.785 .

2. High risk of relapse situations: The test tool developed by Fauziah, et al., (2016) and consists of 3 parts that are related to social-environmental stress (9 items), interpersonal conflict (10 items) and negative emotions (10 items) used to measure the high risk of relapse situations among drug offenders. The reliability value of this scale is high at .885 .

Both test tools used in this study use a four-scale Likert Scale with a choice of answers, namely (1) strongly disagree, (2) disagree, (3) agree and (4) strongly agree.

Data Analysis: Data were analysed using the "Statistical Package for the Social Science for Windows" (SPSS for Windows). Descriptive analysis such as frequency, mean, mode, median, percentage and standard deviation were used to measure the types of coping strategies used by drug offenders. On the other hand, inference analysis (correlation test) is used to measure the relationship between coping strategies with high-risk situations of relapse among drug offenders. The interpretation of this correlation relationship is based on Guildford's (1973) Rule of Thumb' as in Table 2 below: 
Table 2: The Interpretation of strength of correlation based on Guildford's (1973) Rule of Thumb'

\begin{tabular}{c|l|}
\hline Pearson Correlation $(r)$ & Strength of Relationship \\
\hline$<.20$ & Slight relationship \\
.20 to .40 & Low correlation \\
.41 to .70 & Moderate correlation \\
.71 to .90 & High correlation \\
$>.90$ & Very high correlation \\
\hline
\end{tabular}

\section{Research Results and Discussion}

Coping Strategies: Based on the analysis conducted on 301 drug offenders showed that the majority of them chose to use problem-solving coping strategies (mean $=3.4$ ) and emotionally focused coping strategies (mean $=3.3$ ) to overcome drug-related problems (Table 1 ). Simultaneously, the mean score of the avoidance-focused coping strategy recorded a mean score of 2.8. This research shows that drug offenders try to quit drugs and use effective methods to overcome drug problems in themselves. The drug offenders also use emotionally focused coping strategies by using cognitive processes to divert attention to overcome drug problems in their lives.

Table 1: Mean Score of Action Strategies Among Drug offenders in Malaysian Prisons.

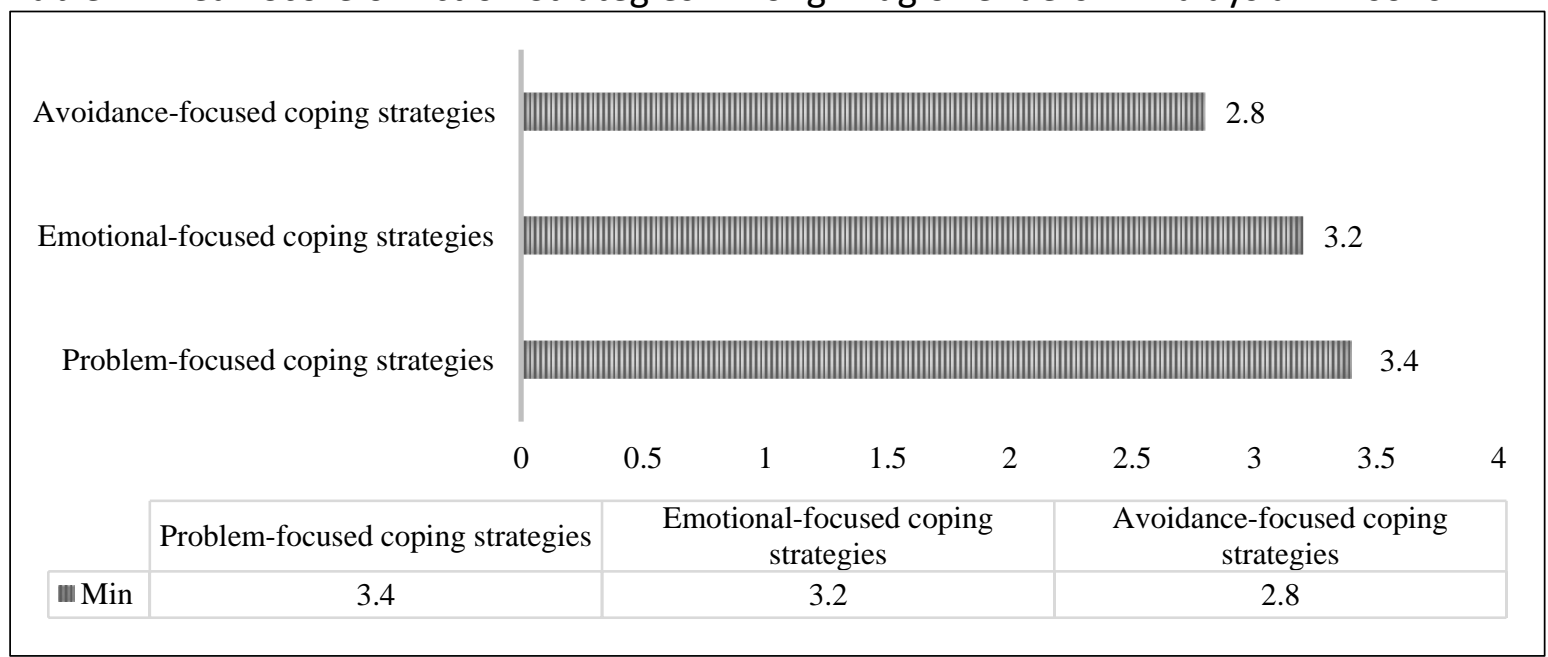

Note: $<2.00$ (low mean score) 2.01-3.00 (medium mean score) 3.01 (high mean score)

Problem-focused coping strategies: Problem-focused coping strategies are coping strategies that seek to eliminate or change the source of stress (Lazarus, 1993). In the context of th is research, the source of stress refers to the drug problem. Analysis of the study showed that a total of $96 \%$ of drug offenders admitted that they were trying to quit drugs (item 1 ). Meanwhile, a total of $79.2 \%$ of drug offenders admit that they know how to overcome drugrelated problems (item 2 ) and use religious practices as the best way for them to forget drugs (79.2\% -item 3). The majority of $96.4 \%$ of the prisoners were also seen to have the determination to improve and admitted that they would seek help from reliable people to give up drugs $(92.4 \%$-item 5$)$.

Emotional-focused coping strategies: Emotional-focused coping strategies refer to the prisoners' ability to solve drug problems faced using an emotional management approach. 
Analysis indicated that $97.5 \%$ of drug offenders admitted that they could be completely drugfree (item 6). The majority of drug offenders involved in this research seem not reluctant to change and leave drugs (95.3\% - item 10), receive good emotional support from others $(93.4 \%$ - item 7), can express feelings to others if they feel unhappy (82.6\% - item 8$)$ and accept that crying can give solace to calm their feelings when faced with adversity (68.8\% - item 11). A total of $88.9 \%$ of drug offenders also admitted to being able to control their anger after quitting drugs (item 9).

Avoidance-focused coping strategies: Avoidance-focused coping strategies refer to less effective methods of avoiding drug problems. Based on the analysis, the research found that the majority of $96.8 \%$ of prisoners chose to conduct other activities to forget about drugs (item 12). The research also realised that a total of $52.8 \%$ of drug offenders still can not accept the fact that they are drug addicts (item 13), choose drugs as a way for them to forget the problem (60.5\% - item 14) and easily give up to recover from drug influence ( $50.4 \%$ - item 15$)$. The findings are significant indications that there are still among drug offenders who are undergoing treatment, and detainees in prisons choose a less effective coping strategy in dealing with drug problems in their life. A total of $73.4 \%$ of drug offenders also admitted to often blaming themselves for being involved with drugs (item 16). This condition, if left untreated, can lead to a high risk of relapse and recidivism problems.

Table 2: Percentage Distribution of Drug-Free Coping Strategy Items

\begin{tabular}{|c|c|c|c|c|c|c|}
\hline \multirow{7}{*}{ No. } & \multirow{7}{*}{ Item } & \multirow{7}{*}{$\begin{array}{l}\text { St } \\
\text { ro } \\
\text { ng } \\
\text { ly } \\
\text { Di } \\
\text { sa } \\
\text { gr } \\
\text { ee }\end{array}$} & \multirow{7}{*}{$\begin{array}{l}\text { Di } \\
\text { sa } \\
\text { gr } \\
\text { ee }\end{array}$} & \multirow{7}{*}{$\begin{array}{c}\mathrm{Ag} \\
\text { re } \\
\mathrm{e}\end{array}$} & \multirow{7}{*}{$\begin{array}{c}\text { St } \\
\text { ro } \\
\text { ng } \\
\text { ly } \\
\mathrm{Ag} \\
\text { re } \\
\text { e }\end{array}$} & \multirow{7}{*}{$\begin{array}{c}\text { Mea } \\
\mathrm{n}\end{array}$} \\
\hline & & & & & & \\
\hline & & & & & & \\
\hline & & & & & & \\
\hline & & & & & & \\
\hline & & & & & & \\
\hline & & & & & & \\
\hline & & $\begin{array}{c}P \\
(\%)\end{array}$ & $\begin{array}{l}\mathrm{P} \\
(\%)\end{array}$ & $\begin{array}{l}P \\
\%)\end{array}$ & $\begin{array}{l}P \\
(\%)\end{array}$ & \\
\hline & \multicolumn{6}{|l|}{ Problem-focused Strategy } \\
\hline 1. & I am trying to quit drugs & 1.2 & 2.7 & 46.4 & 49.6 & 3.44 \\
\hline 2. & I know how to deal with drug problems & 2.7 & 18.2 & 51.4 & 27.8 & 3.04 \\
\hline 3. & $\begin{array}{l}\text { Religious practices helped me to forget } \\
\text { drug problem }\end{array}$ & 0.7 & 5.2 & 36.6 & 57.5 & 3.51 \\
\hline 4 & I am determined to change for the better & 1.5 & 2.2 & 36.4 & 60.0 & 3.55 \\
\hline \multirow[t]{2}{*}{5.} & $\begin{array}{l}\text { I will seek help from reliable person to } \\
\text { give up drugs }\end{array}$ & 1.7 & 5.9 & 44.0 & 48.4 & 3.39 \\
\hline & Emotional-focused Strategy & & & & & \\
\hline 6. & I can be drug free & 1.5 & 1.0 & 27.0 & 70.5 & 3.67 \\
\hline 7. & I receive emotional support from others & 2.0 & 4.7 & 49.4 & 44.0 & 3.35 \\
\hline 8. & $\begin{array}{l}\text { I will express my feelings if I am not } \\
\text { happy }\end{array}$ & 3.9 & 13.5 & 50.9 & 31.7 & 3.10 \\
\hline 9. & $\begin{array}{l}\text { I can control my anger after quitting } \\
\text { drugs }\end{array}$ & 3.7 & 7.4 & 48.9 & 40.0 & 3.25 \\
\hline
\end{tabular}


10 I am not reluctant to change and give up

11. Crying can calm my feelings during difficult times

\section{Avoidance-focused Strategy}

12. I chose other activities to forget drugs

13. I cannot accept the fact that I am a drug addict

14. I choose drugs to forget about problems

15. I easily give up on being drug free

16. I often blame myself for being involved in drugs

$\begin{array}{lrrrr}2.7 & 2.0 & 36.1 & 59.2 & 3.52 \\ 8.8 & 22.4 & 39.8 & 29.0 & 2.89\end{array}$

$\begin{array}{ccccc}0.7 & 2.5 & 47.9 & 48.9 & 3.45 \\ 11.1 & 36.1 & 36.1 & 16.7 & 2.58 \\ & & & & \\ 11.8 & 27.8 & 44.5 & 16.0 & 2.65 \\ 15.7 & 33.9 & 36.9 & 13.5 & 2.48 \\ 8.6 & 17.9 & 50.1 & 23.3 & 2.88\end{array}$

Relationship Between Response Strategies and Relapse High-Risk Situations: Pearson correlation analysis discovered a positive, very weak, but significant relationship between coping strategies $(r=.162 * *, k<0.01)$ with high-risk relapse situations among drug offenders. The results give the impression that coping strategies have a relationship with high-risk relapse situations among drug offenders. Based on the research results, the research hypothesis $\left(\mathrm{H}_{1}\right)$, which predicts a significant relationship between coping strategies with highrisk relapse situations among drug offenders, is acceptable.

Table 4: Relationship between Coping Strategies and High-Risk Relapse Situations.

\begin{tabular}{|l|c|c|}
\hline \multirow{2}{*}{ Variables } & \multicolumn{2}{|c|}{ High-Risk Relapse Situation } \\
\cline { 2 - 3 } & Correlation Value $(\mathrm{r})$ & Significant Level $(\mathrm{k})$ \\
\hline Coping Strategy & $.162^{* *}$ & .001 \\
\hline
\end{tabular}

Note: ${ }^{* *}$ significant at 0.01 confidence level

The results suggested that coping strategy skills play an important role in fighting the warning signs of relapse addiction tendencies. In fact, coping strategies are also significant predictors of treatment outcomes received in the drug recovery process (Litt et al., 2003). Effective coping strategies by focusing on finding solutions to their problems help to deal with stress and indirectly improve their well-being.

\section{Conclusion}

Drug-free coping strategies are seen as an alternative to alleviate the effects of drug demand on an individual. Effective drug-free coping strategies can stimulate the positive attitudes and thoughts of prisoners involved with drugs and can indirectly reduce stress. In summary, the research discovers that most prisoners still use effective coping strategies to free themselves from drugs, that is, by adopting an approach to solve drug problems in their lives. However, there are also drug offenders who use avoidance-focused coping strategies. This approach needs to be given due emphasis because it can lead to drug reuse activities after released from prison if not correctly addressed. The analysis also revealed that coping strategies have a significant relationship with high-risk situations of relapse. The research results give important implications to stakeholders, especially drug rehabilitation counsellors, psychologists and social workers involved in drug treatment and rehabilitation to provide effective education, drug rehabilitation and skills training programs to prisoners. 


\section{Acknowledgement}

The researchers would like to acknowledge the Ministry of Higher Education (MOHE) (FRGS/1/2018/SS06/UKM/02/2) for funding this research. Appreciation is also extended to the Malaysian Prison Department, Faculty of Social Sciences and Humanities, UKM, and everyone who has contributed to the completion of this study.

\section{References}

Arikunto, S. (2006). Prosedur Penilaian Suatu Pendekatan Praktik. Edisi ke-6. Jakarta: Penerbit PT Rineka Cipta.

Annis, H. M., Sklar, S. M., \& Moses, A. E. (1998). Gender in relation to relapse crisis situations, coping and outcomes among treated alcoholics. Addictive Behaviors, 23(1), 127-131.

Arena C. K., Aiman, U. A. S, Jamiah, M. (2017). The effects of Spirituality Aspect towards Coping Strategies among Early Adult Women. Journal of Social Science and Humanities, 3(2017), 1-12

Brechting, E. H., \& Giancola, P. R. (2007). A longitudinal study of coping strategies and substance use in adolescent boys. Journal of Child \& Adolescent Substance Abuse, 16(2), 51-67.

Dennis, M. L., Foss, M. A., Scott, C. K. (2007). An eight-year perspective on the relationship between the duration of abstinence and other aspects of recovery. Evaluation Review, 31(6), 585-612.

Dennis, M. L., Scott, C. K., Funk, R., Foss, M. A. (2005). The duration and correlates of addiction and treatment careers. Journal of Substance Abuse Treatment, 28(1), 51-62.

Eitlea, T. M., \& Eitlea D. J. (2015). Race, coping strategies and substance use behaviors: A preliminary analysis examining white and American Indian adolescents. Substance Use Misuse, 49(3), 315-325.

Fauziah, I., Ezarina, Z., Salina, N., Norulhuda, S., Siti Mariam, M. (2016). Kecenderungan relaps dan kejayaan mengekalkan kepulihan dalam kalangan penghuni yang tamat mengikuti rawatan dan pemulihan di Cure \& Care Rehabilitation Centre (CCRC). Laporan Akhir Penyelidikan: Geran Penyelidikan IImiah AADK

Fauziah, I., Bahaman, A. B., Mansor, A. T., Mohamad, S., S. (2012). Drug addicts and the highrisk situations of relapse. Journal of Social Sciences and Humanities, 7(1), 1-13.

Gossop, M., Stewart, D., Browne, N., \& Marsden, J. (2002). Change and stability of change after treatment of drug misuse 2-year outcomes form the National Treatment Outcome Research Study (UK). Addictive Behaviors, 27(2), 155-166.

Ison, M. G., Gubareva L. V., Atmar R. L., Treanor, J., Hayden F. G. (2006). Recovery of drugresistant influenza virus from immunocompromised patients: a case series. Journal Infectious Disease, 193(6), 760-764.

Hasking, P. A., \& Oei, T., P. (2002). Confirmatory factor analysis of the COPE questionnaire on community drinkers and an alcohol-dependent sample. Journal of Studies on Alcohol, 63(5), 631-640.

Hasking, P. A., Scheier, L. M., and Abdallah, A. B. (2011). The three latent antisocial classes of adolescent delinquency and the risk factors for membership in each class. Aggress. Behav. 37(1), 19-35.

Hadijah, B., Shahrazad, W. S., Fauziah, I., Norulhuda, S. (2018). Faktor-faktor penyumbang kecenderungan situasi berisiko tinggi dalam kalangan penagih dadah berulang di Malaysia. Jurnal Psikologi Malaysia, 32(2), 1-11. 
Kiluk, B., D., Nich, C., \& Carroll, K. M. (2011). Relationship of cognitive function and the acquisition of coping skills in computer assisted treatment for substance use disorders. Drug and Alcohol Dependence, 114(2-3), 169-176.

Lazarus, R. S. (1993). Psychological stress and the coping process. New York: McGraw-Hill

Litt, M. D., Kadden, R. M., Cooney, N. L., \& Kabela, E. (2003). Coping skills and treatment outcomes in cognitive-behavioral and interactional group therapy for alcoholism. Journal of Consulting and Clinical Psychology, 71(1), 118-128

Murnizam, H., Sharon, K., Sam, M., Norzihan, A., Patricia, J. K., Voo, P., \& Su, K. (2011) Persepsi keberkesanan program pemulihan, strategi daya tindak dan proses niat untuk penagihan berulang dalam kalangan bekas penagih Methamphetamine. Jurnal Antitidadah Malaysia, 7(1), 137-161

Mahmood, N. M., Shuaib, C. D., \& Lasimon, M. (1999). Penentu psikososial terhadap penagihan semula di kalangan penagih dadah psikoaktif. Laporan Kajian UUM-IRPA.

Mustapha, S., Z., Harith, N. H. M., \& Ismail, T. N. T. (2020). Sustainable Drug Treatment and Rehabilitation Programme in Malaysia-Empowering the Client through "555 NoteBook." International Journal of Academic Research in Business and Social Sciences, 10(14), 70-81.

Nur Saadah, M. A., \& Hilwa, A. (2015). Coping Strategy and Social Support Program for Informal Caregivers. Journal of Social Science and Humanities, 10(1), 171-183.

Norhayati, I., Asmawati, D., Norella K., C. T. (2015). Kesan pengantara strategi daya tindak agama terhadap hubungan di antara kemurungan dan kualiti hidup pesakit buah pinggang tahap akhir. Jurnal Psikologi Malaysia, 29(1), 52-62.

Sanchez, M., Rice, E., Stein, J., Milburn, N. G., Rotheram-Borus, M., J. (2010). Acculturation, coping style and health risk behaviors among HIV positive Latinas. AIDS Behavior, 14(2), 401-409.

Sussman, S. (2012). Substance and behavioral addictions: Co-occurrence and specificity. International Journal of Environmental Research and Public Health, Special Issues, 8, 3399-3415.

Sinha R. (2008). Chronic Stress. Drug Use, and Vulnerability to Addiction. Annals of the New York Academy of Science, 1141(1), 105-130.

Razali, A. (2018). Relationship Between the Coping Factor and the Inclination to Relapse among Former Drug Addicts. International Journal of Academic Research in Business and Social Sciences, 8(10), 1404-1416.

Valentino, R. J., Lucki, I., \& Van Bockstaele, E. (2010). Corticotropin-releasing factor in the dorsal raphe nucleus: Linking stress coping and addiction. Brain Research, 16(1314), 2937.

Walsh, K., Fortier, M., \& Dilillo, D. (2010). Adult coping with childhood sexual abuse: A theoretical and empirical review. Aggression and Violent Behavior, 15(1), 1-13. 